\title{
DISTRIBUTION OF Zanthium indicum AROUND GIRITALE TANK
}

\author{
S Maithripala and G I Seneviratne \\ Department of Botany \\ University of Colombo.
}

The area around Giritale tank is the main grazing ground of wild and domestic animals within the nature reserve and there has been an increase in the population of Xamthium indicum (Agada) in this areal. In the Flora of Ccylon Trimen recorded this as a rare plant probably introduced from India. Today, it is reported to be present in more than 7 districts of the country. mostly in moist areas periodically inundated. It reduces the grazing capacity and the hooked involucres are reported to cause damage to the internal organs of the grazers. Studies are being carried out to find the distribution and suitable control measures.

Area around the tank was sampled at $100 \mathrm{~m}$ intervals. The plant is capable of producing flowers and fruits irrespective of the time of the year and the size of the plant. When less than $50 \%$ of the areat was covered by the plant the ahundance wals taken. as low and when it was more than $50 \%$, as high. $53 \%$ of the total area has been identified as high abundance and only $9 \%$ as free.

The species has already spread from the edge of watter towards the forest. Although the fruits are found, the plant has not established in the forest. Soil moisture, texture and the light intensity determine the growth of this plant. Fruits get embedded in the mud and alter decomposition two achenes are released which germinate later. There are reports of $X a m t h i u m$ sp. producing two types of achenes, germinating in consecutive years. Studies are being carried out to investigate this.

To improve the grazing capacity of the area it is necessary to control the growth of this plant. Controlled burning seems to be the best. Ten other species have been recorded growing with Agalda. Crotalaria pallida competes with $X$. Indicum, reducing its population. The possibility of use of Cuscuta chinensis in the control of Xamthium indicum is being tested. 